\title{
Characteristics of Comprehending Evidential Markers and Words for Korean Preschool Children with Specific Language Impairment
}

\author{
Myeong-Eun Song ${ }^{a}$, Hee Ran Lee ${ }^{b}$ \\ ${ }^{a}$ Department of Speech and Hearing Therapy, Graduate School of Catholic University of Pusan, Busan, Korea \\ ${ }^{b}$ Department of Speech and Hearing Therapy, Catholic University of Pusan, Busan, Korea
}

Correspondence: Hee Ran Lee, PhD Department of Speech and Hearing Therapy, Catholic University of Pusan, 57 Oryundae-ro, Geumjeong-gu, Busan 46252, Korea

Tel: $+82-51-510-0841$

Fax: $+82-51-510-0848$

E-mail: hrlee@cup.ac.kr

Received: January 5, 2019

Revised: February 20, 2019

Accepted: March 7, 2019
Objectives: This study is designed to study the ability of children with specific language impairment (SLI) and typically developing (TD) children to comprehend the source of information in sentences using grammatical markers and words that present evidentiality. Methods: Fifteen 5- to 6-year-old children with SLI and 15 age-matched TD children participated in this study. The children were tested with comprehension tasks using sentences which include grammatical markers (direct experience '-nae', indirect inference '-geot gata') and words (direct experience 'see', indirect inference 'think') that indicate the source of information. Results: The SLI groups exhibited difficulty in the tasks that asked them to choose between direct experience markers ('-nae') and indirect inference markers ('-geot gata'). The differences between these groups were significant. Also, there were differences in the comprehension of the evidential markers and words in each group. There were no significant differences in the group of SLI. However, there were significant differences following the evidential markers and words in the group of TD children. Conclusion: Children with SLI had difficulty comprehending both grammatical markers and words in which both experience and inference were presented when compared to TD children. This study has clinical significance in that it shows that children with developmental language disorders have difficulties in the use of high frequency evidentiality grammatical markers and words that are learned at an early development stage and used for discourse.

Keywords: Specific language impairment, Evidential marker, Evidential word, Sentence comprehension
학령전 아동의 발달에서 어휘를 포함한 언어의 각 영역들은 각 각의 발달 과정을 통해 지속적으로 상호작용하며 함께 발달한다. 아동은 12 개월경에 의미 있는 첫 낱말을 표현하고, 이후 두 낱말을 조합하여 의미론적 관계를 표현하면서 문법형태소를 산출하기 시 작한다. 또한 인지발달과 더불어 성인과의 상호작용이 더해지면서 점차 다양한 어휘와 문법형태소를 사용하여 단문보다 복문을 더 많이 사용하게 된다. 5 세 이후 아동은 점차 의미론적 지식에 대해 문장형식의 발달이 함께 이루어지고, 좀 더 복잡하거나 예측과 추 론이 포함되어야 하는 수준의 이야기들도 표현할 수 있게 된다. 특
히, 이들의 언어능력은 이후 문해력을 포함한 학령기와 성인기의 언 어능력에까지 영향을 미치게 되므로 매우 중요하게 다뤼진다(Ludden, 2016). 무엇보다 학령기를 앞둔 만 5, 6세경의 아동들은 모든 언어영역의 발달이 안정적으로 이루어지며, 이 시기는 다양한 담화 맥락에서 의사소통을 하기 위한 준비단계라고 볼 수 있다. 학령전 기의 아동이 자신이 직접 경험했던 행동이나 사건을 통해 다양한 세상사 정보를 얻게 되는 경우에 비해, 이 시기 아동들은 스스로 직 접 경험한 정보뿐만 아니라 새로운 환경에서 타인과의 다양한 상호 작용을 통해 얻는 간접적인 정보들 또한 받아들이게 된다(Lee \& 
Lee, 2016). 즉, 다양한 담화맥락에서 입력되는 많은 정보를 듣고, 이를 화자로서 전달할 수 있어야 하는 시기에 직면한 만 5,6 세 아 동들은 정보를 얻은 방법과 출처를 판단하는 능력이 중요하다고 할수 있다.

여러 담화맥락에서 성공적인 의사소통을 하기 위해서는 상대방 과 공통 기반(common ground)을 형성하여 상대방이 제공하는 정 보를 정확하게 받아들이는 것이 중요하며, 이러한 점은 다른 사람 의 마음을 이해하는 능력과도 연관되어 있다(Aksu-Koc \& Alici, 2000; Choi, Lee, \& Jang, 2010; Choi, Jang, \& Lee, 2011; Lee \& Lee, 2016). 일반적으로 의사소통 과정에서 화자와 청자 간에 주고 받는 문장에서 표현되는 문법표지(grammatical marker)와 어휘에 따라 정보의 확실성과 신뢰성이 다르게 표현되기도 하는데, 이를 증거성 체계(evidentiality)라고 한다(Aikhenvald, 2004). 즉, 대화상황에서 화자와 청자 각자의 역할 수행에서 정보의 출처를 알려주는 증거성 표지와 어휘에 대한 표현과 이해가 매우 중요하다. 한국어에서 주 로 사용하는 증거성 표지는 '-네', '-대', '-것 같다' 등이 있다. 우리말 과는 달리 영어에서는 주로 문법표지가 아닌 어휘로 정보의 출처를 표시하는데, 가장 흔하게 사용하는 증거성 어휘로는 'see', 'hear', 'guess' 등이 있다(Papafragou, Li, Choi, \& Han, 2007). 이처럼 각 언어에는 고유의 형태로 정보의 출처가 포함되는 증거성 표시 체계 가 있으며, 이에 더해 경험이나 추론처럼 그 정보를 어떻게 얻었는 지에 따른 정보의 출처를 나타내기 위한 범주들을 구분하여 사용 하기도 한다(Davis, Potts, \& Speas, 2007; Speas, 2004).

정보의 출처에 따라 증거성의 범주를 구분하는 것과 관련하여, $\operatorname{Kim}$ (2012)은 동일한 정보일지라도 화자의 시각과 관점으로 이루 어진 직접적인 정보는 간접경험이나 추론보다 더 높은 신뢰를 드러 낸다고 제안하였다. 즉, 한 개인이 특정 상황에서 자신의 경험을 통 해 정보를 습득하게 되면 정보의 신뢰성과 확실성이 더 커지게 되 는 반면, 간접적으로 이뤄진 경험이나 추론으로부터 정보를 습득 하게 되면 그 정보가 믿을 만한지에 대해 확신하는 정도가 더 낮아 진다는 것이다. 이를 한국어에 적용해 본다면, 증거성을 표현하는 문법표지 중에서 직접경험은 시제에 따른 현재경험표지인 '-네, -어', 과거경험표지인 '-더-를 들 수 있다. 그 밖에도 간접경험표지 '-대', '-래', 간접추론표지 '-겠', '-것 같다, -나봐’로 나눌 수도 있다(Song, 2007, 2014). 이에 더해 각 범주에 따른 증거성 어휘 유형으로는 화 자가 직접 경험했을 경우의 어휘로는 '보다'를 들 수 있으며, 타인을 통해 간접적으로 경험했을 때는 '듣다', '말하다', '주장하다'가 포함 된다. 하지만, 간접적으로 추론하여 얻은 정보일 경우에는 '생각하 다', ‘추측하다'를 통해 정보의 출처를 표현할 수 있다(Choi, Jang, \& Lee, 2012; Papafragou et al., 2007). 예를 들어, 화자가 ‘아이스크림
이 녹은 것 같아.'라고 말했을 경우, 청자는 '아이스크림이 녹았다' 라는 정보 외에도 '것 같다'라는 문법표지를 통해 아이스크림이 녹았다는 것이 화자가 간접적으로 추측한 정보임을 알아차리게 된 다. 하지만 화자의 직접경험을 표시하는 '네' 표지를 사용한다면 (예: ‘아이스크림이 녹았네’), 청자는 화자가 현재 아이스크림이 녹 은 것을 직접 보면서 전달하고 있다는 것을 알 수 있다. 또한 증거성 어휘의 측면에서도 화자의 추측으로 '아이스크림이 녹았다고 생각 해.라고 말하는 것보다는 화자의 직접경험으로 '아이스크림이 녹 은 걸 봤어.라고 표현하는 것이 정보의 정확성이 더 높다. 이처럼 화 자가 정보를 얻은 방법에 따라 달라지는 정보의 신뢰성과 확실성은 문법표지와 어휘를 통해 달리 표현되므로, 이러한 언어 특성들은 발달기의 아동에게서 중요한 발달 과제라고 할 수 있다.

요약하자면, 화자는 다양한 담화맥락에서 증거성 표지나 증거성 어휘로 청자에게 정보의 출처를 전달하게 되고, 청자는 이를 듣고 정보가 확실하고 믿을 만한지를 판단할 수 있다. 앞에서 살펴본 바 와 같이, 증거성 체계를 잘 이해하는 것은 일상생활에서 여러 통로 를 통해 얻게 된 정보의 확실성을 판단하고 타인에게 전달하는 데 중요한 역할을 하게 되므로, 발달 과정에서 이러한 언어특성들의 습득과 사용은 적극적이고 성공적인 사회적 상호작용을 위한 토대 가 될 것이다.

증거성을 드러내는 문법표지 가운데 가장 먼저 발달하는 직접경 험표지는 '-어'와 '-네'인데, 아동들이 1 세 중반이 되면 산출을 시작 한다. 점차 간접경험을 나타내는 '대'와 같은 종결어미는 2 세경에 자발적인 산출이 가능해지며, 3 세경이면 좀 더 성숙한 수준으로 표 현할 수 있게 된다(Choi et al., 2010, 2011; Lee \& Lee, 2016; Papafragou et al., 2007). 반면, '-것 같다'와같이 간접추론을 의미하는 문법 표지는 5 세가 되어야 자발적으로 표현할 수 있어 보다 습득이 어려 운 것으로 보고되고 있다(Lee \& Lee, 2012). 산출과는 달리, 문법표 지의 이해는 직접경험을 나타내는 '-어(네)'가 2세경에 이해가 가능 해지고, 간접추론표지 '것 같다'는 5세 이후에 빠르게 발달한다. 하 지만 간접경험표지 '-대'는 6세 수준에서도 여전히 어려우며, 학령 기에 이르러야 성숙하게 사용할 수 있다고 알려져 있다(Choi et al., 2011; Lee \& Lee, 2016). 한편, 증거성 어휘의 발달과 관련해서는 만 3 세경 아동들이 직접경험 어휘 '보다'와 간접경험 어휘 ‘듣다'를 듣 고 확실한 정보인지를 정확하게 이해할 수 있었다고 한다(Choi et al., 2010). 즉, 한국어에서 증거성 표지와 어휘의 발달은 산출과 이 해 측면에서 차이를 보이고 있는 것을 알 수 있으며, 연령이 증가하 면서 어휘력과 사회적 상호작용에 더해 정보의 확실성을 표현하고 판단하는 다양한 인지능력이 관여하는 것으로 보인다.

한편, 단순언어장애 아동은 첫 낱말 산출 시기가 일반아동에 비 
해 늦게 출현하고 이후 또래 아동에 비해 습득한 단어의 양이나 사 용하는 능력이 저하되며, 특히 명사보다 동사를 습득하고 사용하 는 데 어려움이 있다(Leonard, 2014; Stokes \& Fletcher, 2000). 또한, 이들은 또래 아동에 비해 문법형태소를 적게 사용했으며 문법적으 로 복잡한 문장을 이해하는 데 어려움이 있었다(Montgomery, Gillam, \& Evans, 2016; Moon, Hwang, \& Choi, 2014). 이러한 언어 의 의미와 형식의 결함은 단순언어장애 아동들의 이후 이야기를 포함한 담화 상황에서 역할을 하는 데에서도 영향을 미치게 된다 (Marini, Gentili, Molteni, \& Fabbro, 2014; Ukrainetz et al., 2005). 무엇보다 단순언어장애 아동이 보이는 의미론적 결함은 문법형태 소와 통사적 구조의 이해와 산출에도 영향을 미치게 되며, 이러한 언어적 측면에서의 어려움은 상대방의 마음을 이해하는 능력과도 관계가 있으므로 사회적 상호작용에 상당한 영향을 미치게 된다 (Farrar et al., 2009). 즉, 언어의 의미와 형식 모두에서 두드러진 어 려움을 보이는 단순언어장애 아동이 어휘와 문법표지로 표현되는 증거성 체계를 이해하는 능력을 살펴보고 그 특성을 고찰해 본다 면, 이들의 언어적 어려움에 대한 보다 실질적인 해석에 좀 더 가깝 게 접근할수 있을 것이다.

최근 연구자들은 단순언어장애 아동이 보이는 언어 의미와 형식 결함의 근본적인 원인을 여러 측면으로 설명하고 있다. Lee와 $\mathrm{Ha}$ (2015)는 단순언어장애 아동의 어휘적 어려움을 장기기억에 저장 된 어휘 개념의 양적인 부족과 관련 지어 설명하고 있는 반면, Yang 과 Yim (2017)은 이들이 문법성 판단에서 보이는 낮은 수행률을 인 지적 유연성(cognitive flexibility)의 저하에 기인한다고 하였다. 또 한, Montgomery 등(2016)은 단순언어장애 아동의 부족한 작업기 억 능력과 문장 이해의 어려움이 여러 언어 결함에 관련되어 있다 고 하였다. 즉, 단순언어장애 아동을 진단하기 위한 많은 배제적 진 단 기준에서는 동작성 지능에 결함이 없음을 가정하고 있지만, 최 근의 여러 연구들에서는 이들의 언어적 어려움을 작업기억을 포함 한 여러 인지 관련 요인과 관련 지어 설명하고 있다. 특히, Drummey와 Newcombe (2002)에 따르면 정보의 확실성을 판단하기 위 해 전제가 되는 증거성 체계의 이해는 작업기억 능력과 관련이 있으 며, 이러한 점은 단순언어장애 아동의 작업기억 능력 부족이 증거 성 체계의 이해와 표현 결함으로 이어질 수 있음을 시사하기 있기 도 하다.

따라서, 본 연구에서는 다양한 담화맥락에서 정보를 듣고 전달 하는 능력이 더 중요해지는 시기에 직면한 만 5,6 세 단순언어장애 아동을 대상으로 증거성 표지와 어휘를 이해하는 능력을 살펴보 고 이를 일반아동과 비교하여 그 특성에 대해 논하고자 한다.

\section{연구방법}

\section{연구대상}

본 연구는 부산에 거주하고 생활연령이 만 5,6 세인 단순언어장 애 아동 15 명, 그리고 이들 아동과 생활연령을 \pm 3 개월 범위 내로 일치시킨 일반아동 15 명, 총 30 명을 대상으로 실시하였다. 일반아 동의 증거성 어휘 이해의 발달을 살펴보면 대체로 3 세부터 증거성 어휘로 제시된 문장을 듣고 확실한 정보를 판단할 수 있었다. 또한, 증거성 표지 이해의 발달은 5 세 때 급격히 이루어졌으나 간접경험 표지의 발달은 6세에도 성숙하지 않았다(Choi et al., 2011). 따라서 선행연구를 참조하여 본 연구에서는 만 5,6 세 아동을 대상으로 직 접경험과 간접추론의 증거성 표지와 어휘로 연구를 진행하였다.

단순언어장애 집단은 Leonard (2014) 기준에 따라서 다음과 같 이 선정하였다. (1) 취학전 아동의 수용언어 및 표현언어 척도(Preschool Receptive-Expressive Language scale, PRES; Kim, Sung, \& Lee, 2003)검사 결과, 수용언어와 표현언어 모두 $10 \%$ ile 이하에 속하 고, (2) 아동용 웩슬러 유아지능검사(Korean Wechsler Preschool and Primary Scale of Intelligence, K-WPPSI; Park, Kwak, \& Park, 1997)결과, 동작성 지능이 85 이상이고, (3) 부모나 유치원 교사 보 고로 시각과 청력, 기타 신경학적 질환, 구강구조와 기능의 이상, 사 회적 상호작용의 능력에 심각한 결함이 없는 아동들로 선정하였다.

일반아동 집단은 (1) 취학전 아동의 수용언어 및 표현언어검사 결과, 수용언어와 표현언어 모두 생활연령에 비해 $10 \%$ ile 이상에 속 하고, (2) 아동용 웩슬러 유아지능검사 결과 동작성 지능이 85 이상 이고, (3) 부모나 유치원 교사 보고로 인지, 신체, 언어발달이 정상 이며 시각과 청각 기타 신경학적 문제가 없는 것으로 보고된 아동 이며, (4) 단순언어장애 아동과 일대일로 대응했을 때 생활연령이 \pm 3 개월 이내인 아동들로 선정하였다.

단순언어장애 아동 집단의 생활연령은 평균 6세(5세 8개월-6세 6 개월)이었으며, 일반아동 집단의 생활연령은 평균 5 세 11 개월(5세 1 개월-6세 4 개월)이었다. 집단에 대한 연령 통제가 잘 이루어졌는 지 확인하기 위해 독립표본 $t$-검정을 실시하였다. 그 결과, 단순언어 장애 아동 집단과 일반아동 집단 간에 생활연령에 따라 유의미한 차이가 없는 것으로 나타났다 $(t=-1.107, p>.05)$ (Table 1).

\section{연구도구}

\section{증거성 과제}

본 연구에서는 단순언어장애 아동이 직접경험과 간접추론을 나 타내는 표지와 어휘의 이해를 살펴보기 위하여 해당 과제를 실시 하였다. 실험 과제는 Song (2014), Choi 등 (2011, 2012), 그리고 Kim, 
Table 1. Characteristics of participants

\begin{tabular}{lccc}
\hline Characteristic & SLI group (N=15) & TD group (N=15) & $t$ \\
\hline Age $(\mathrm{mo})$ & $72.93(2.98)$ & $71.27(5.00)$ & -1.107 \\
Nonverbal I0 & $94.20(6.78)$ & $96.80(6.42)$ & 1.077 \\
\hline
\end{tabular}

Values are presented as mean (SD).

$\mathrm{SLI}=$ children with specific language impairment; TD=children with typical development.

aKorean Wechsler Preschool and Primary Scale of Intelligence (Park, Kwak, \& Park, 1997).

Hong, Kim, Jang과 Lee (2009)를 참조하여 만 5, 6세 아동이 쉽게 이해할 수 있는 2-4어절의 문장으로 수정하여 사용하였다.

문항 선정을 위해 부산 지역의 어린이집에 다니는 만 5,6 세 일반 아동 2 명과 단순언어장애 아동 2 명을 대상으로 예비연구를 실시하 였다. 예비연구 결과를 토대로 하여 아동들이 이해하기 어려워하 는 사건문장과 사건그림을 제외하고 증거성 표지와 어휘에 대한 연 습문항을 각각 1 개씩 추가하였다. 예비연구에서 각 문항마다 제시 되는 두 개의 진술은 주어를 사람(예: 엄마, 아빠, 친구)으로 하였으 나, 아동은 진술을 듣고 주어와 관련된 개인적인 경험을 바탕으로 반응하였다. 따라서 사건에 대한 진술의 주어는 동물(예: 곰, 토끼, 고양이 등)로 수정하였다.

문항수는 '직접경험과 간접추론 증거성 표지'와 '직접경험과 간 접추론 증거성 어휘' 이해를 확인하기 위해 사건별로 연습문항 1 개 와 본 문항 20 개씩, 총 42 개로 구성하였다. 문항은 정보의 출처에 따 라서 신뢰성과 확실성이 달라짐을 이해하는지 살펴보기 위해 화자 본인의 경험을 뜻하는 '직접경험'과 일부 정보만으로 추측된 보고 인 '간접추론'의 증거성 표지와 어휘를 사용하여 제작하였다. 증거 성 표지 문항은 직접경험표지 '-네', 간접추론표지 '-것 같다', 증거 성 어휘 문항은 직접경험어휘 '보다', 간접추론어휘 '생각하다'로 제 작하였다. 검사자는 한 장의 사건그림을 가리키며 이에 대한 사건 문장(예: '색연필이 부러졌어')을 들려준 후, 인물카드 두 장을 순서 대로 가리키며 직접경험(예: '초록색 색연필이 부러졌네')과 간접추 론(예: '파란색 색연필이 부러진 것 같아')에 대한 각각의 진술을 아 동에게 들려주었다. 아동의 과제는 두 장의 인물카드 중에서 더 정 확한 진술을 하는 인물카드를 손가락으로 가리키는 것이었다. 과제 에서 사용한 사건문장과 진술은 Appendix 1에 제시하였다. 과제는 증거성 표지에 대한 문항과 어휘에 대한 문항을 무작위로 실시하 여 아동이 일관된 반응을 보이지 않도록 구성하였다.

증거성 과제에서 사용된 사건그림은 아동의 반응에 미치는 영향 을 최소화하기 위해서 흰 바탕에 검정색 선화로 제작되었다. 아동 에게 제시되는 사건그림의 크기는 가로 $12 \mathrm{~cm} \times$ 세로 $10 \mathrm{~cm}$ 이며 인 물카드는 가로 $8 \mathrm{~cm} \times$ 세로 $8 \mathrm{~cm}$ 로 제작되었다(Appendix 2).
타당도

아동에게 제시되는 사건문장과 사건그림, 직접경험과 간접추론 으로 표현된 증거성 표지와 어휘의 진술이 증거성 이해를 살펴보기 위한 측정치로 적합한가에 대해 내용타당도를 검증받았다. 내용타 당도는 언어재활사 1 급 자격증과 박사학위 소지자인 3 명의 전문가 에게 평가받았다. 3 명의 전문가는 증거성 과제에서 사용되는 사건 문장과 그림, 증거성 표지와 어휘의 진술에 대한 타당도를 Likert 5 점 척도 $(1=$ 매우 부적절, $2=$ 부적절, $3=$ 보통, $4=$ 적절, $5=$ 매우 적 절)로 평가하였으며, 그 결과 사건문장 내용타당도 평균은 4.67 , 사 건그림 내용타당도의 평균은 4.51 , 증거성 표지와 어휘 진술 평균은 4.59로 나타났다. 내용타당도 평가 결과, 3점 이하의 문항과 증거성 이해를 확인하기 어려운 진술과 사건문장, 사건이 명확하게 드러나 지 않는 사건그림을 제외하거나 수정하여 사용하였다. 증거성 과제 는 두 차례에 걸쳐 수정하였으며, 2 차 수정은 위 3 명의 전문가 중 1 명의 전문가와 함께 진행하였다.

\section{연구절차}

검사는 아동이 다니는 어린이집과 유치원을 직접 방문하여 아동 과 일대일로 검사를 진행하였다. 검사자는 아동이 다니는 어린이집 과 유치원을 1 차로 방문하여 대상자를 선정하기 위해 선별검사를 실시한 후, 실험 과제는 2 차로 방문하여 실시하였다. 본 연구에서 실시하는 두 가지 선별검사는 순서효과를 배제하기 위해 무선화하 여 실시하였다.

검사자는 책상에 아동과 마주보고 앉아서 검사를 진행하였다. 검사자는 아동에게 “지금부터 선생님이 그림을 보여주면서 이야기 를 들려줄 거야. 이야기를 듣고 선생님이 물어보는 거에 대답해줘." 라고 실험과제 절차에 대해서 충분히 설명을 한 후 연습문항을 먼 저 실시하였다. 연습문항에서는 "선생님이 위에 있는 그림에 대해 서 이야기를 들려줄 거야. 그리고 그림에 대한 두 사람의 이야기도 들려줄 거야. 둘 중에 더 정확한 이야기를 하는 사람을 손가락으로 가리켜줘.”라고 아동에게 들려주었다. 이후 검사자는 사건그림을 가리키며 사건문장을 들려주고 인물카드를 순서대로 가리키며 직 접경험과 간접추론에 대한 각각의 진술을 아동에게 들려주었다. 그 다음, 검사자는 “누구 말이 더 정확한 거 같아?”라고 질문한 후 아동이 두 장의 인물카드 중에서 더 정확한 진술을 하는 인물카드 를 손가락으로 가리키도록 하였다. 아동이 그림을 정확하게 가리키 지 않았을 경우에 검사자는 아동에게 손가락으로 그림을 다시 짚 어달라고 요청하였다. 이러한 과정으로 검사자는 아동이 실험과제 를 정확하게 이해하였는지 확인하였다. 연습문항에서 아동이 실험 과제를 올바르게 이해하지 못하였을 경우에는 위의 과정을 다시 설 
명해준 후 본 문항을 실시하였다. 본 문항에서는 연습문항의 절차 와 동일한 과정으로 진행하였다. 하지만 아동이 사건에 대한 문장 이나 진술을 한 번 더 들려달라고 요청하는 경우 2 회에 한해 더 들 려주었다. 검사자는 문항에 대한 사건과 진술 이야기가 모두 끝난 후 7초 이내에 아동이 반응을 보이지 않으면 다음 문항으로 넘어갔 다. 실험 과제를 모두 실시하는 데는 8-10분 정도 소요되었다.

\section{자료분석}

검사자는 실험을 진행하는 동안 아동의 반응을 바로 검사지에 기록하였다. 채점 기준은 아동이 두 개의 진술 중에서 직접경험 증 거성 표지나 증거성 어휘에 대한 인물카드를 가리켰을 경우 1점, 간 접추론 증거성 표지나증거성 어휘에 대한 진술을 가리키거나 모르 겠다고 반응을 보인 경우는 0 점으로 하였다. 따라서 아동이 모두 정반응을 보인 경우에 증거성 표지에 대한 문항에서 20점, 증거성 어휘에 대한 문항에서 20 점을 부여하였다.

\section{신뢰도}

실험 과제에 대한 신뢰도를 검증하기 위하여 평가자 간 신뢰도를 산출하였다. 평가자 간 신뢰도는 언어재활사 2 급 자격증을 소지한 2 명의 대학원생에게 검사 절차, 기록, 그리고 채점 방법을 상세히 설 명한 후 전체 수집된 자료의 $30 \%$ 를 임의로 선정하여 채점하도록 하였다. 그 결과 검사자 간 채점 신뢰도는 $99 \%$ 였다.

\section{통계분석}

단순언어장애 아동과 일반아동이 증거성 표지와 어휘를 듣고 문장을 이해하는 능력에 차이를 보이는지 살펴보기 위해IBM SPSS Statistics 23 프로그램을 사용하여 독립표본 $t$-검정을 실시하였다. 또한 단순언어장애 아동과 일반아동이 각 집단 내에서 증거성 표 지와 어휘를 이해하는 데 차이가 있는지를 살펴보기 위해 대응표 본 $t$-검정을 실시하였다.

\section{연구결과}

\section{두 집단의 증거성 표지와 어휘 이해}

단순언어장애 아동 집단과 일반아동 집단이 증거성 표지와 어휘 가 포함된 문장을 이해하는 정도를 비교한 결과, 직접경험에 대한 사건문장을 듣고 직접경험과 간접추론에 대한 각각의 진술을 하 는 사람 가운데 직접경험을 진술한 사람을 선택하는 점수는 단순 언어장애 아동 집단이 일반아동 집단보다 더 낮았다. 단순언어장 애 아동 집단은 증거성 표지와 어휘 모두에서 일반아동 집단보다
Table 2. Comparison of evidentiality comprehension between SLI and TD

\begin{tabular}{lccc}
\hline & SLl group $(\mathrm{N}=15)$ & TD group $(\mathrm{N}=15)$ & $t$ \\
\hline Evidential markers & $10.40(2.77)$ & $16.60(2.97)$ & $5.909^{*}$ \\
Evidential words & $10.07(2.49)$ & $18.07(1.66)$ & $10.333^{*}$ \\
\hline
\end{tabular}

Values are presented as mean (SD).

$S L I=$ children with specific language impairment; $T D=$ children with typical development.

${ }^{*} p<.05$.

낮은 점수를 보였다. 두 집단의 차이가 통계적으로 유의미한지 살 펴보기 위해 독립표본 $t$-검정을 실시한 결과, 증거성 표지 $(t=5.909$, $p<.05)$ 와 증거성 어휘 $(t=10.333, p<.05)$ 모두에서 유의미한 차이 가 있는 것으로 나타났다(Table 2).

\section{집단 내에서 증거성 표지와 어휘 이해의 차이}

두 집단의 증거성 표지와 어휘의 이해를 각각 분석한 결과, 기술 통계에서는 단순언어장애 아동 집단의 경우, 증거성 어휘보다는 증 거성 표지에서 더 높은 점수를 보였다. 그러나 대응표본 $t$-검정을 실 시한 결과에서는 증거성 표지와 증거성 어휘 간에 통계적으로 유의 미한 차이가 나타나지 않았다 $(t=-.303, p>.05)$. 하지만, 일반아동 집단에서는 증거성 어휘에서 더 높은 점수를 보였으며, 증거성 표지 와 어휘 간에 통계적으로도 유의미한 차이가 있는 것으로 나타났 다 $(t=2.509, p<.05)$.

\section{논의 및 결론}

본 연구는 만 5,6 세 단순언어장애 아동이 직접경험과 간접추론 을 나타내는 우리말의 문법표지와 어휘를 이해하는지를 사건문장 에 이어지는 진술문장의 이해 과제를 통해 알아보고자 하였다. 이 를 위해 증거성 문법표지로는 직접경험의 '네'와 간접추론의 '-것 같다’를 살펴보았으며, 어휘로는 직접경험의 '보다'와 간접추론의 '생각하다'에 대한 이해를 일반아동 집단과 비교하였다. 아동들에 게는 직접경험을 나타내는 사건문장(예: ‘색연필이 부러졌어')을 들 려주고, 직접경험(예: ‘초록색 색연필이 부러졌네')과 간접추론(예: '파란색 색연필이 부러진 것 같아')을 말하는 두 인물 중 직접경험 을 말하는 인물을 선택하게 하는 이해 과제를 수행하게 하였다.

연구 결과, 단순언어장애 아동 집단은 일반아동 집단보다 증거 성 표지와 증거성 어휘 이해 모두에서 어려움을 보였으며, 이러한 차이는 통계적으로도 유의미하였다. 즉, 단순언어장애 아동은 직 접경험표지와 어휘, 간접추론표지와 어휘를 듣고 신뢰성과 확실성 이 더 높은 문장이 무엇인지 판단하는 데에 어려움이 있는 것으로 해석할 수 있었다. Choi 등 $(2010,2011)$ 은 만 3-6세의 일반아동의 
경우, 증거성 범주 중에서 직접경험표지와 어휘로 진술한 문장의 신뢰성이 가장 높다는 것을 이해한다고 보고하였다. 일반아동은 자신이 직접 눈으로 확인하지 않았더라도 화자가 직접 체험한 내용 을 진술하는 '사건문장'에서 나타나는 경험과 추론의 증거성 체계 를 이해할 수 있었던 것이다. 하지만 본 연구에서처럼 단순언어장 애 아동은 화자가 말하는 문장에서 직접경험표지와 어휘, 그리고 간접추론표지와 어휘에 따라서 정보의 정확성이 달라짐을 이해하 기에는 어려움이 있었다. 단순언어장애 아동 집단이 일반아동과 비교해 이처럼 정보 원천의 확실성을 구분하는 문장 이해에 어려 움이 있다는 것에는 여러 가지 해석이 있을 수 있겠지만, 무엇보다 문장 내 어휘 정보의 의미 각각이 맥락 정보에 따라 달라질 수 있다 는 사실에 대한 파악이 어려운 점을 들 수 있을 것이다.

본 연구결과에서 단순언어장애 아동은 증거성 표지와 어휘 점수 에서 유의미한 차이가 나타나지 않았다. 하지만 일반아동은 증거 성 표지에 비해 증거성 어휘에서 점수가 높았다. 이는 일반아동의 경우, 직접경험표지 '-네’보다 직접경험어휘 '보다’로 정확한 정보를 더 능숙하게 판단하는 것으로 볼 수 있다. 이와 관련해서 Choi 등 (2010)의 연구에서도, 만 3-6세의 일반아동 대부분은 증거성 표지 보다 증거성 어휘를 듣고 정확한 정보가 무엇인지를 더 능숙하게 확인할 수 있었다고 하였다. 일반적으로 학령전 아동은 문장의 의 미를 해석할 때 의미적 단서를 주로 사용하고 학령기에 이르면 의 미단서보다 문법형태소를 더 활용하여 문장을 이해한다(Bates, Devescovi, \& Wulfeck, 2001). 선행연구의 결과에 비추어 보았을 때, 본 연구에서 단순언어장애 아동이 보인 어려움은 증거성 어휘 이해의 제한적인 능력이 증거성 표지 이해에도 영향을 미치는 것으 로 해석된다. 이를 고려하여, 학령전 단순언어장애 아동의 중재 시 에는 직접경험 어휘의 중재를 먼저 실시하여 화자의 경험이나 추론 에 따라 정보의 확실성과 신뢰성이 달라짐을 이해할 수 있도록 교 육할수 있어야 할 것이다.

무엇보다 본 연구의 결과를 통해, 발달 초기에 습득되는 고빈도 의 문법표지와 어휘일지라도 경험과 추론이라는 증거성 체계로써 맥락 정보를 활용해야 하는 담화 수준에서 사용될 때는 언어장애 아동에게 특정 어려움이 있음을 확인하였으므로, 이러한 중요성이 중재에 적용될 수 있도록 학문적 논의가 계속적으로 진행되어야 할 것이다.

선행연구들에서는 증거성 체계의 이해와사용이 다양한 인지능 력과 관련되어 있다고 보고하고 있다(Drummey \& Newcombe, 2002; Matsui \& Fitneva, 2009; Papafragou et al., 2007). 특히, 대화 과정에서 정보의 원천에 대한 문법표지 또는 어휘가 사용될 때, 그 정보의 직접성이나 정확성, 추론을 통한 진위 여부를 확인하기 위
해서는 이러한 문법 정보와 어휘 정보에 덧붙여, 정보를 언제, 어디 에서, 누구를 통해, 어떤 방식으로 전달받았는지 확인하고 기억하 며 처리하는 능력이 무엇보다 필요하다. 또한 대화 상황에서 정보 의 확실성과 신뢰성을 증거성 표지와 어휘로 표현하거나 이를 판단 할 때에는 상대방의 마음을 이해하는 능력도 밀접하게 관련되어 있다(Aksu-Koc \& Alici, 2000; Choi et al., 2010, 2011; Kyuchukov \& de Villiers, 2009; Lee \& Lee, 2016; Matsui, Rakoczy, Miura, \& Tomasello, 2009). 즉, 단순언어장애 아동이 증거성 체계를 이해하 는 데 어려움을 보이는 것에 대하여 어휘와 표지뿐만 아니라 마음 이론과 같은 인지능력도 고려해야 할 필요성이 있는 것으로 볼 수 있다. 따라서, 본 연구에서 단순언어장애 아동이 드러낸 문법표지 와 어휘로 제공되는 맥락 정보에 대한 정보 원천 파악의 어려움이 마음이론과 같은 타인의 마음을 이해하는 능력과 관련이 있는지 를 추후연구에서 면밀하게 살펴보는 것도 의미가 있을 것이다.

기존의 증거성 표지와 어휘의 이해를 살펴보는 선행연구들의 경 우, 실험과정에서 동영상으로 등장인물의 상황을 추론하게 하거 나, 검사자와 함께 실험에 참여하여 직접 상황을 이해하고 산출하 게 하는 등 과제 난이도가 비교적 높았다. 따라서 본 연구에서는 이 를 해결하기 위해 간단한 사건문장과 사건그림을 사용하였다. 그럼 에도 아동들이 주어진 사건문장을 듣고 이에 관련된 보다 정확한 진술을 찾아내는 과제 수행의 과정은 선행연구와 동일하게 아동들 이 화용적 맥락을 좁혀 해석하기에는 많은 어려움이 있었던 것으로 보인다. 이러한 점은 추후연구에서 고려되어야 할 사항으로 남는다.

\section{REFERENCES}

Aikhenvald, A. Y. (2004). Evidentiality. Oxford: Oxford University Press.

Aksu-Koc, A., \& Alici, D. M. (2000). Understanding sources of beliefs and marking of uncertainty: the child's theory of evidentiality. In E. V. Clark (Ed.), The proceedings of the thirtieth child language research forum (pp. 123-130). Stanford, CA: Center for the Study of Language and Information.

Bates, E., Devescovi, A., \& Wulfeck, B. (2001). Psycholinguistics: a cross-language perspective. Annual Review of Psychology, 52(1), 369-396.

Choi, Y., Jang, N., \& Lee, H. (2011). Development of evidentiality: production, comprehension and it's relation to theory of mind. Korean Journal of Developmental Psychology, 24(1), 93-108.

Choi, Y., Jang, N., \& Lee, H. (2012). Factors affecting Korean preschoolers' evidential reasoning: trust in testimony and understanding of evidential markers. Korean Journal of Developmental Psychology, 25(1), 135-152. 
Choi, Y., Lee, H., \& Jang, N. (2010). Development of understanding the relationship between information source and certainty. Korean Journal of Developmental Psychology, 23(2), 109-124.

Davis, C., Potts, C., \& Speas, M. (2007). The pragmatic values of evidential sentences. Semantics and Linguistic Theory, 17, 71-88.

Drummey, A. B., \& Newcombe, N. S. (2002). Developmental changes in source memory. Developmental Science, 5(4), 502-513.

Farrar, M. J., Johnson, B., Tompkins, V., Easters, M., Zilisi-Medus, A., \& Benigno, J. P. (2009). Language and theory of mind in preschool children with specific language impairment. Journal of Communication Disorders, 42(6), 428-441.

Kim, J. (2012). A study on the terminologies of Korean semantics. Korean Semantics, 39, 101-124.

Kim, Y. T., Hong, G. H., Kim, K. H., Jang, H. S., \& Lee, J. Y. (2009). Receptive \& expressive vocabulary test (REVT). Seoul: Seoul Community Rehabilitation Center.

Kim, Y. T., Sung, T. J., \& Lee, Y. K. (2003). Preschool receptive-expressive language scale (PRES). Seoul: Seoul Community Rehabilitation Center.

Kyuchukov, H., \& De Villiers, J. (2009). Theory of Mind and evidentiality in Romani-Bulgarian bilingual children. Psychology of Language and Communication, 13(2), 21-34.

Lee, E. Y., \& Ha, J. W. (2015). Semantic representation in children with specific language impairment. Communication Sciences \& Disorders, 20(2), 277-289.

Lee, J. H., \& Lee, H. R. (2016). The relationship between evidentiality development and theory of mind in school-aged children. Communication Sciences \& Disorders, 21(2), 206-216.

Lee, S., \& Lee, H. (2012). The astonishing language development of children. Seoul: Hakjisa.

Leonard, L. B. (2014). Children with specific language impairment (2nd ed.). Cambridge, MA: MIT Press.

Ludden, D. (2016). The psychology of language: an integrated approach. Thousand Oaks, CA: Sage Publications.

Marini, A., Gentili, C., Molteni, M., \& Fabbro, F. (2014). Differential verbal working memory effects on linguistic production in children with specific language impairment. Research in Developmental Disabilities, 35(12), 3534-
3542.

Matsui, T., \& Fitneva, S. A. (2009). Knowing how we know: evidentiality and cognitive development. New Directions for Child and Adolescent Development, 2009(125), 1-11.

Matsui, T., Rakoczy, H., Miura, Y., \& Tomasello, M. (2009). Understanding of speaker certainty and false-belief reasoning: a comparison of Japanese and German preschoolers. Developmental Science, 12(4), 602-613.

Montgomery, J. W., Gillam, R. B., \& Evans, J. L. (2016). Syntactic versus memory accounts of the sentence comprehension deficits of specific language impairment: looking back, looking ahead. Journal of Speech, Language, and Hearing Research, 59(6), 1491-1504.

Moon, H., Hwang, M., \& Choi, K. S. (2014). The comprehension and production of three Korean semantic particles (nun, man, do) in Korean children with specific language impairment. Communication Sciences \& Disorders, 19(4), 447-455.

Papafragou, A., Li, P., Choi, Y., \& Han, C. H. (2007). Evidentiality in language and cognition. Cognition, 103(2), 253-299.

Park, H., Kwak, K., \& Park, K. (1997). Korean-Wechsler Preschool and Primary Scale of Intelligence (K-WPPSI). Seoul: Seoul Community Rehabilitation Center.

Song, J. M. (2007). Typology of evidentiality and subject restriction: based on Korean, Mongolian and Tibetan. Morphology, 9(1), 1-23.

Song, J. M. (2014). Evidential suffix -ney in Korean: a reply to Chung (2007, 2012). Korean Journal of Linguistics, 39(4), 819-850.

Speas, M. (2004). Evidentiality, logophoricity and the syntactic representation of pragmatic features. Lingua, 114(3), 255-276.

Stokes, S. F., \& Fletcher, P. (2000). Lexical diversity and productivity in Cantonese-speaking children with specific language impairment. International Journal of Language \& Communication Disorders, 35(4), 527-541.

Ukrainetz, T. A., Justice, L. M., Kaderavek, J. N., Eisenberg, S. L., Gillam, R. B., \& Harm, H. M. (2005). The development of expressive elaboration in fictional narratives. Journal of Speech, Language, and Hearing Research, 48(6), 1363-1377.

Yang, Y., \& Yim, D. (2017). The relationship of grammatical judgment and implicit learning in 4-to 6-year-old children with and without specific language impairment. Communication Sciences \& Disorders, 22(1), 35-46. 
Appendix 1. 실험에서 사용한 사건문장과 진술

\begin{tabular}{|c|c|c|c|}
\hline & 사건문장 & 증거성 표지 진술 & 증거성 어휘 진술 \\
\hline \multirow[t]{2}{*}{ 연습 문제 A } & 돼지가 노래를 불렀어. & - & 돼지가 마이크로 노래를 불렀다고 생각해. \\
\hline & & - & 돼지가 피아노를 치면서 노래하는 걸 봤어. \\
\hline \multirow[t]{2}{*}{ 연습 문제 B } & 고양이가 그림을 그렸어. & 고양이가 무지개를 그린 것 같아. & - \\
\hline & & 고양이가 집을 그렸네. & - \\
\hline \multirow[t]{2}{*}{1} & 색연필이 부러졌어. & 파란색 색연필이 부러졌네. & 파란색 색연필이 부러졌다고 생각해. \\
\hline & & 빨간색 색연필이 부러진 것 같아. & 초록색 색연필이 부러진 걸 봤어. \\
\hline \multirow[t]{2}{*}{2} & 아이스크림이 녹았어. & 딸기맛 아이스크림이 녹은 것 같아. & 초코맛 아이스크림이 녹은 걸 봤어. \\
\hline & & 초코맛 아이스크림이 녹았네. & 딸기맛 아이스크림이 녹았다고 생각해. \\
\hline \multirow[t]{2}{*}{3} & 가게에 도둑이 들었어. & 도둑이 초콜릿을 훔친 것 같아. & 도둑이 사탕을 훔치는 걸 봤어. \\
\hline & & 도둑이 사탕을 훔쳤네. & 도둑이 초콜릿을 훔쳤다고 생각해. \\
\hline \multirow[t]{2}{*}{4} & 물감이 묻었어. & 물감이 옷에 묻었네. & 물감이 손에 묻었다고 생각해. \\
\hline & & 물감이 손에 묻은 것 같아. & 물감이 옷에 묻은걸 봤어. \\
\hline \multirow[t]{2}{*}{5} & 의자에 상자를 놔뒀어. & 토끼가 상자를 놔뒀네. & 원숭이가 상자를 놔두는 걸 봤어. \\
\hline & & 원숭이가 상자를 놔둔 것 같아. & 토끼가 상자를 놔두었다고 생각해. \\
\hline \multirow[t]{2}{*}{6} & 곰이 위층으로 올라갔어. & 곰이 계단으로 올라갔네. & 곰이 계단으로 올라가는 걸 봤어. \\
\hline & & 곰이 엘리베이터를 타고 올라간 것 같아. & 곰이 엘리베이터를 타고 올라갔다고 생각해. \\
\hline \multirow[t]{2}{*}{7} & 토끼가 바닷가에 갔어. & 토끼가 수영을 한 것 같아. & 토끼가 수영하는 걸 봤어. \\
\hline & & 토끼가 모래놀이를 했네. & 토끼가 모래놀이를 했다고 생각해. \\
\hline \multirow[t]{2}{*}{8} & 곰이 선물을 받았어. & 곰이 선물로 신발을 받은 것 같아. & 곰이 선물로 모자를 받았다고 생각해. \\
\hline & & 곰이 선물로 모자를 받았네. & 곰이 선물로 신발을 받은 걸 봤어. \\
\hline \multirow[t]{2}{*}{9} & 돼지가 영화를 봤어. & 돼지가 주스를 마시면서 영화를 봤네. & 돼지가 사이다를 마시면서 영화 보는 걸 봤어. \\
\hline & & 돼지가 사이다를 마시면서 영화를 본 것 같아. & 돼지가 주스를 마시면서 영화를 봤다고 생각해 \\
\hline \multirow[t]{2}{*}{10} & 토끼가 마트에서 우유를 샀어. & 토끼가 초코우유를 샀네. & 토끼가 바나나우유를 샀다고 생각해. \\
\hline & & 토끼가 딸기우유를 산 것 같아. & 토끼가 딸기우유를 산 걸 봤어. \\
\hline \multirow[t]{2}{*}{11} & 꽃이 피었어. & 분홍색 꽃이 핀 것 같아. & 노란 꽃이 피었다고 생각해. \\
\hline & & 주황색 꽃이 피었네. & 분홍 꽃이 핀 걸 봤어. \\
\hline \multirow[t]{2}{*}{12} & 고양이가 풍선을 불었어. & 고양이가 파란색 풍선을 분 것 같아. & 고양이가 초록색 풍선을 부는 걸 봤어. \\
\hline & & 고양이가 분홍색 풍선을 불었네. & 고양이가 보라색 풍선을 불었다고 생각해. \\
\hline \multirow[t]{2}{*}{13} & 곰이 놀이터에서 놀았어. & 곰이 그네를 탄 것 같아. & 곰이 그네를 탔다고 생각해. \\
\hline & & 곰이 미끄럼틀을 탔네. & 곰이 미끄럼틀을 탄 걸 봤어. \\
\hline \multirow[t]{2}{*}{14} & 원숭이가 나무에서 떨어졌어. & 원숭이가 떨어져서 다리를 다쳤네. & 원숭이가 떨어져서 팔을 다쳤다고 생각해. \\
\hline & & 원숭이가 떨어져서 팔을 다친 것 같아. & 원숭이가 떨어져서 다리를 다친 걸 봤어. \\
\hline \multirow[t]{2}{*}{15} & 곰이 컵을 쳤어. & 곰이 우유를 쏟은 것 같아. & 곰이 우유를 쏟았다고 생각해. \\
\hline & & 곰이 물을 쏟았네. & 곰이 물을 쏟은 걸 봤어. \\
\hline \multirow[t]{2}{*}{16} & 고양이가 칼로 잘랐어. & 고양이가 오이를 잘랐네. & 고양이가 칼로 수박을 잘랐다고 생각해. \\
\hline & & 고양이가 수박을 자른 것 같아. & 고양이가 칼로 오이 자르는 걸 봤어. \\
\hline \multirow[t]{2}{*}{17} & 문이 열려있어. & 곰이 문을 열었네. & 곰이 문을 여는 걸 봤어. \\
\hline & & 돼지가 문을 연 것 같아. & 돼지가 문을 열었다고 생각해. \\
\hline \multirow[t]{2}{*}{18} & 토끼가 컵에 물을 부었어. & 토끼가 파란 컵에 물을 부은 것 같아. & 토끼가 빨간 컵에 물을 부은 걸 봤어. \\
\hline & & 토끼가 빨간 컵에 물을 부었네. & 토끼가 파란 컵에 물을 부었다고 생각해. \\
\hline \multirow[t]{2}{*}{19} & 고양이는 배가 고파. & 고양이가 배고파서 피자를 먹은 것 같아. & 고양이가 배고파서 햄버거를 먹는 걸 봤어. \\
\hline & & 고양이가 배고파서 햄버거를 먹었네. & 고양이가 배고파서 피자를 먹었다고 생각해. \\
\hline \multirow[t]{2}{*}{20} & 고양이가 씻었어 & 고양이가 손을 씻었네. & 고양이가 손을 씻었다고 생각해. \\
\hline & & 고양이가 발을 씻은 것 같아. & 고양이가 발을 씻는 걸 봤어. \\
\hline
\end{tabular}


Appendix 2. 증거성 과제의 예시

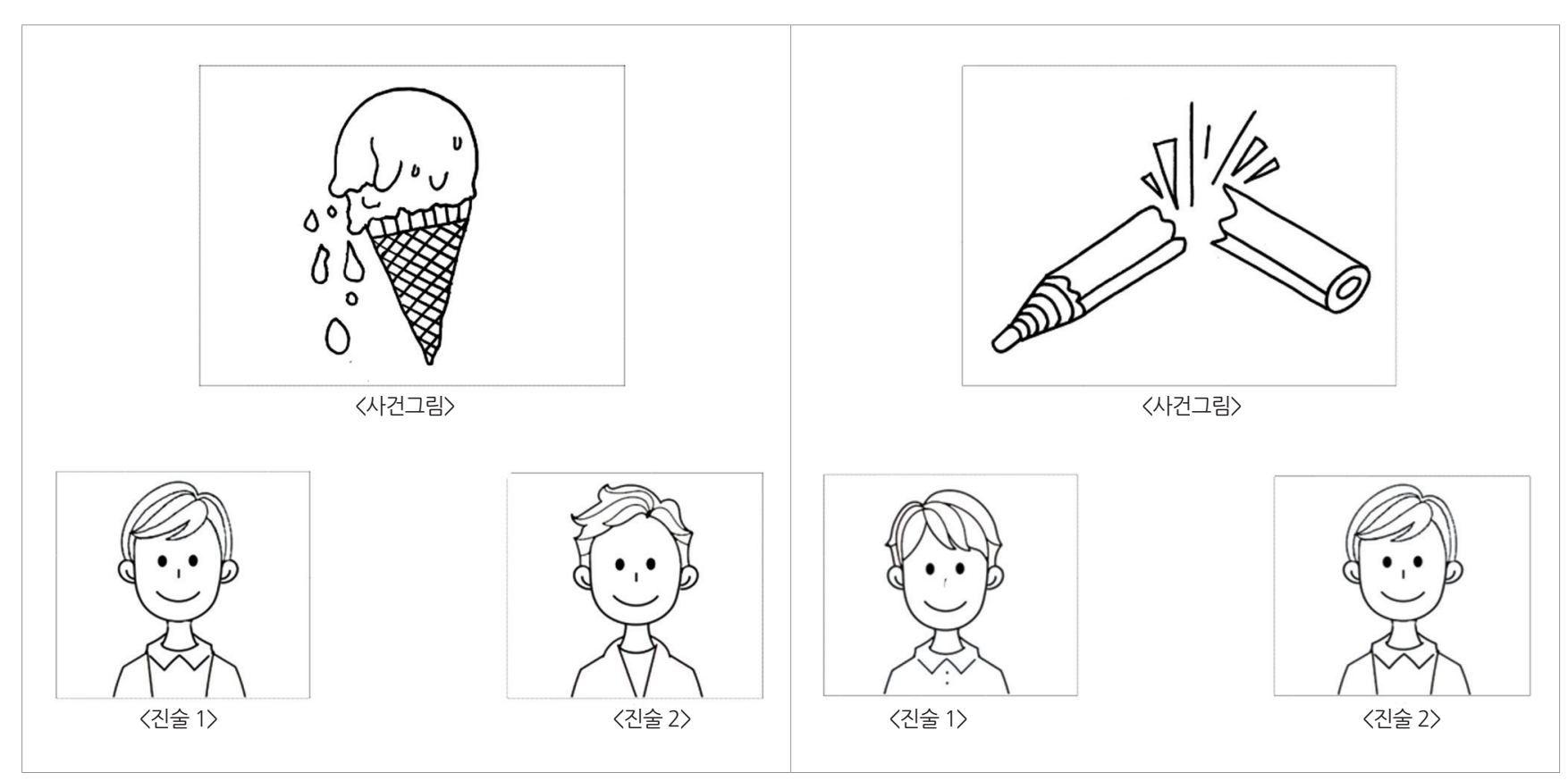




\section{국문초록}

\section{학령전 단순언어장애 아동의 증거성 표지와 어휘 이해 특성 \\ 송명은 $\cdot$ 이희란 \\ 1부산가톨릭대학교대학원 언어청각치료학과, ${ }^{2 ㅂ ㅜ ㅅ ㅏ ㄴ ㄱ ㅏ ㅌ ㅗ ㄹ ㄹ ㅣ ㄱ ㄷ ㅐ ㅎ ㅏ ㄱ ㄱ ㅛ ~ ㅇ ㅓ ㄴ ㅇ ㅓ ㅊ ㅓ ㅇ ㄱ ㅏ ㄱ ㅊ ㅣ ㄹ ㅛ ㅎ ㅏ ㄱ ㄱ ㅘ ~}$}

배경 및 목적: 본 연구에서는 학령전 단순언어장애 아동이 화자가 전달하려는 정보의 출처와 확실성을 이해하는 데 필요한 증거성 체 계로서의 문법표지와 어휘를 이해하는 특성을 살펴보고자 하였다. 방법: 연구대상은 만 5,6 세 단순언어장애 아동 15 명, 일반아동 15 명 으로 총 30명이었다. 이들을 대상으로 문법표지 '네(직접경험)'와 ‘-것 같아(간접추론)', 그리고 어휘 ‘보다(직접경험)', '생각하다(간접추 론)'가 포함된 문장에 대한 이해 과제를 실시하였다. 결과: 단순언어장애 아동 집단은 직접경험을 나타내는 사건문장을 듣고 나서 직접 경험표지 ‘-네’와 간접추론표지 ‘-것 같아’의 진술 가운데 직접경험을 선택하는 이해 과제에서 일반아동보다 수행에 어려움이 있었으며, 이러한 집단 간 차이는 통계적으로도 유의미하였다. 또한, 단순언어장애 아동 집단은 증거성 표지와 증거성 어휘를 이해하는 수행 간에 유의미한 차이가 나타나지 않았으나, 일반아동 집단은 증거성 표지보다는 증거성 어휘가 포함된 문장 이해 수행 정도가 더 높았으며, 이 러한 차이는 통계적으로도 유의미하였다. 논의 및 결론: 단순언어장애 아동은 일반아동과 달리 경험과 추론을 나타내는 문법표지와 어휘 이해 모두에서 어려움이 있었다. 본 연구의 결과를 통해, 발달 초기에 습득되는 고빈도의 문법표지와 어휘일지라도 경험과추론이 라는 증거성 체계로써 맥락정보를 활용해야 하는 담화 수준에서 사용될 때는 언어장애 아동에게 특정 어려움이 있으므로, 이러한 중 요성이 중재에 적용될 수 있어야 함을 논의하였다.

핵심어: 단순언어장애, 증거성 표지, 증거성 어휘, 문장 이해

\section{참고문헌}

김영태, 성태제, 이윤경(2003). 취학전 아동의 수용언어 및 표현언어 척도(PRES). 서울: 서울장애인종합복지관.

김영태, 홍경훈, 김경희, 장혜성, 이주연(2009). 수용·표현어휘력검사(REVT). 서울: 서울장애인종합복지관.

김진웅(2012). 한국어 증거성의 체계: 유형론을 중심으로. 한국어 의미학, 39, 101-124.

문현아, 황민아, 최경순(2014). 단순언어장애 아동의 보조사 이해 및 산출: '은/는, '만', ‘도를 중심으로. Communication Sciences \& Disorders, 19(4), 447-455.

박혜원, 곽금주, 박광배(1997). 한국-웩슬러 유아지능검사(K-WPPSI). 서울: 도서출판 특수교육.

송재목(2007). 증거성(evidentiality)과주어제약의 유형론: 한국어, 몽골어, 티벳어를 예로 들어. 형태론, 9(1), 1-23.

송재목(2014). 한국어 증거성 종결어미 "-네”: 정경숙(2007, 2014)에 대한 대답. 언어, 39(4), 819-850.

양윤희, 임동선(2017). 4-6세 단순언어장애 및 일반아동의 암묵적 학습 및 문법성 판단능력의 관계. Communication Sciences \& Disorders, 22(1), 35-46. 이승복, 이희란(2012). 아이와 함께하는 신기한 언어발달. 서울: 학지사.

이은영, 하지완(2015). 단순언어장애 아동과 일반 아동의 의미표상 비교. Communication Sciences \& Disorders, 20(2), 277-289.

이지현, 이희란(2016). 학령기 아동의 문법표지 발달과마음이론간의 관계: 경험과추론을 중심으로. Communication Sciences \&Disorders, 21(2), $206-216$. 최영은, 이화인, 장나영(2010). 정보 원천 표현에 따른 정보 확실성 이해의 발달. 한국심리학회지: 발달, 23(2), 109-124.

최영은, 장나영, 이화인(2011). 증거성표지의 이해, 산출과 마음이론발달의 관련성 연구. 한국심리학회지: 발달, 24(1), 93-108.

최영은, 장나영, 이화인(2012). 학령전기 아동의 증언 판별, 증거성 표지 이해와 정보확실성 판단 능력 발달. 한국심리학회지: 발달, 25(1), 135-152.

\section{ORCID}

송명은(http://orcid.org/0000-0003-1770-3389); 이희란(http://orcid.org/0000-0002-7898-4623) 